\title{
The Impact of Perceived Supervisor Support on OCB: The Moderating Effect of Introversion
}

\author{
Naheed Sultana*, Osaid Rabie ${ }^{* *}$, Mariam Farooq ${ }^{* * *}$ and \\ Ayesha Amjad ${ }^{* * *}$
}

\begin{abstract}
This study examines the extent to which introversion moderates the relationship between perceived supervisor support and organizational citizenship behavior (OCB). Based on a sample of 586 employees working in Pakistan's education sector, we find that introverts have a positive moderating effect on the indirect relationship between perceived supervisor support, work engagement and OCB. This suggests that supervisor support fosters work engagement and, in turn, $O C B$.
\end{abstract}

Keywords: Supervisor support, organizational citizenship behavior, personality, introversion.

JEL classification: M19.

\section{Introduction}

Supervisors are a key part of the management hierarchy and play an important role in monitoring and training employees. They are also responsible for mediating between senior management and operational employees ( $\mathrm{Lu} \& \mathrm{Lin}, 2014)$. Thus, they serve as problem solvers, designing procedures and policies and developing the skills and competencies needed to improve the quality of employees' daily tasks (Azman et al., 2009).

Supervisors are also responsible for providing employees with professional support and resources for development, removing any obstacles to their work and offering feedback on the latter's work. Ismail et al. (2010) show that supervisors have a positive impact on employee

\footnotetext{
* Professor, University of Lahore.

${ }^{* * *}$ Lecturer, University of Lahore.

*** Assistant professor, University of Central Punjab

${ }^{* * * *}$ Research scholar, University of Lahore.
} 
performance: their role involves training and motivating employees to develop their skills and improve their job performance.

In this context, supervisor support refers to the extent to which supervisors value their employees' work and care about their wellbeing (Liaw, Chi \& Chuang, 2010). In turn, employees know that supervisors are responsible for evaluating their performance and see supervisor support as an indication of organizational support (Rhoades \& Eisenberger, 2002).

The literature demonstrates the positive outcomes of supervisor support, including greater job satisfaction, organizational commitment, better working relationships with other employees, a willingness to assume additional responsibilities and lower levels of job tension and work-family conflict (Rhoades \& Eisenberger, 2002). Job satisfaction as a result of better supervisor support strongly affects turnover intention (Galletta et al., 2011). Moreover, employees with higher levels of supervisor support experience less job stress, role conflict and role ambiguity (Steinhardt et al., 2003).

Eisenberger et al. (2002) investigate the relationship between perceived supervisor support (PSS) and employee turnover, moderated by perceived organizational support (POS). They find that both PSS and POS have a significant positive effect on employee turnover. The relationship between PSS, affective commitment and performance is also positive, but with other variables affecting the relationship between supervisor support and performance (Soulen, 2003). Coworker support, for instance, is also important in motivating employees to innovate and engage with their work (Arora \& Kamalanabhan, 2013).

While organizational citizenship behavior (OCB) is not a formal job requirement, nor is it formally rewarded or recognized, it has a positive impact on organizational performance (Emami et al., 2012). OCB may be reflected in performance appraisals when supervisors and coworkers are favorably rated. This, in turn, leads to lower turnover intention and enhances job satisfaction and employee productivity (Lapierre \& Hackett, 2007). Certain, though not all, personality types are correlated with OCB. Effective leadership, the social environment and supervisor awareness are all factors that determine OCB in the workplace (Zhang, 2011). Higher levels of OCB induce employee loyalty at an emotional and cognitive level (Paillé \& Grima, 2011).

Section 2 reviews the literature on the outcomes of PSS and the impact of this construct on work engagement (WE) and OCB. In Section 3, 


\section{Introversion}

we hypothesize that PSS has a positive effect on OCB through the mediating role of WE. The boundary condition applied here is that introversion can strengthen or weaken the latter. Section 4 describes the data and methodology used. Section 5 presents our findings and Section 6 discusses the results. Section 7 concludes the study, outlines its limitations and suggests future directions for research.

While many studies have looked at the relationship between PSS and OCB (see, for example, Chen \& Chiu, 2008; Wang, 2014), very few have employed WE as a mediator. Chen and Chiu (2008) demonstrate that job satisfaction moderates the relationship between PSS and OCB, while Deniz, Noyan and Ertosun (2015) examine the relationship between person-organization fit and job stress. However, other variables too can affect the relationship between PSS and OCB. We seek to address this gap in the literature by using extraversion and introversion as moderators. Under social exchange theory, we argue that PSS induces WE and, in turn, leads to OCB.

\section{Conceptual Background}

Chen and Chiu (2008) demonstrate the relationship between PSS and OCB using two cognitive mechanisms (job satisfaction and personorganization fit) and one effective mechanism (job tension). Their results build on social exchange theory, which holds that supervisor support will lead to OCB through different cognitive mechanisms. The presence of PSS drives employees to reciprocate and maintain the social exchange between employee and organization. Supervisor support helps them recognize the extent to which they are well matched to the firm.

When PSS enhances job satisfaction, employees are more likely to engage in OCB. Job stress, on the other hand, will have a negative effect on OCB. Ismail et al. (2010) conclude that supervisor support in the form of training programs plays a key role in employee learning. A good supervisor will explain firm procedures, goals and tasks effectively, thereby motivating employees to learn new skills and perform better. Under expectancy theory, employees will only be motivated to carry out a certain task if they perceive its value in terms of a return.

Maertz et al. (2007) describe the relationship between PSS, POS and turnover intention, based on the theory of social exchange and reciprocity: employees who receive support from their organization and supervisor will feel obligated to the firm. PSS and POS induce many employee 
outcomes, including OCB and job performance, and directly influence turnover. Here, PSS is a stronger determinant of turnover than POS.

Griffin, Patterson and West (2001) show that PSS has a greater impact in companies where employees do not work in teams. This does not imply, however, that supervisor support is not important in teamwork situations because it is still positively correlated with job satisfaction. A higher level of teamwork may have a negative impact on job satisfaction because employees who are given more autonomy - and thus more responsibility - find greater job satisfaction.

Bolino, Turnley and Bloodgood (2002) argue that OCB enhances firm performance because it creates social capital. Behaviors such as obedience, loyalty and functional participation create trust and identification among employees. This has a positive effect on cognitive behavior and produces a shared language. Thus, social capital mediates the positive relationship between OCB and organizational performance.

Kidd and Smewing (2001) show that greater trust and autonomy between supervisors and employees increase the latter's organizational commitment. They use gender as a moderating variable in this relationship and find that an increase in supervisor support is associated with higher organizational commitment in the case of female employees. The results for male employees are more complex: both high and low levels of supervisor support have a positive linear relationship with organizational commitment, while moderate levels of support are associated with decreasing organizational commitment.

Baloyi, van Waveren and Chan (2014) demonstrate that PSS acts as a mediator, but not a moderator, in the relationship between performance management systems and perceived job satisfaction. Employees who receive a positive performance management response attribute this to higher levels of supervisor support and report greater job satisfaction. Conversely, a poor performance management response is associated with lower levels of supervisor support and job dissatisfaction.

DeConinck and Johnson (2009) show that better supervisor support improves performance and reduces turnover among salespersons. They find that PSS and POS mediate the relationship between organizational justice and employee turnover. Calderón, Battistelli and Odoardi (2013) establish that WE is determined by PSS and by employees' participation in decision making (the extent to which employees feel their input is valued). 
Kuvaas and Dysvik (2010) argue that perceived investment in employee development mediates the relationship between PSS and employee outcomes. Under the theory of organizational support and social exchange, employees who feel they are valued by their supervisors and organization reciprocate with better performance, greater effort, effective organizational commitment and low turnover intentions. Similarly, Byrne et al. (2012) demonstrate that PSS influences the relationship between organizational justice (informational and interpersonal) and the extent to which employees trust their supervisors' appraisal decisions.

Neves and Caetano (2009) show that PSS mediates the relationship between supervisor competence and commitment to change. Using organizational support theory, the authors explain that competent supervisors are perceived as being more supportive because they do not see their employees as a threat. Thus, supervisor competence has a positive relationship with both normative and effective commitment to change, but is negatively associated with continuance commitment to change. Bhatnagar (2014) uses a multilevel model to show that PSS has a positive impact on innovation. Stronger levels of supervisor support create mutual expectations of input and outcomes. Employees who perceive that their work is valued in the form of reward and recognition are more likely to display innovative behavior.

Barnard's (1938) theory of equilibrium supports the relationship between PSS and the psychological contract, which underlines the significance of a task. Rashid et al. (2012) show that supervisor support reduces work-related stress as well as family-versus-work conflict among employees. In turn, PSS has a significant, positive effect on job satisfaction. Paillé and Grima (2011) find that OCB is negatively related to an employee's intention to leave his/her current organization. In organizations that foster higher levels of $\mathrm{OCB}$, employees are likely to prefer changing jobs within the same organization to leaving it altogether.

\section{Hypothesis Development}

This section draws on the literature supporting our hypotheses.

\subsection{PSS and $O C B$}

OCB is constructive behavior: employees choose to help their coworkers, which in turn benefits the company (Organ, 1997). Supervisors who value their employees' work and help them develop the skills and competencies needed to achieve the organization's goals create higher 
levels of motivation and job satisfaction (Chen \& Chiu, 2008; Foote \& Tang, 2008; Podsakoff et al., 2000). This improves person-organization fit and OCB among employees (Liaw et al., 2010). It also creates mutual trust between supervisors and their employees (Organ, Podsakoff \& MacKenzie, 2006) and reduces job stress (Brough \& Pears, 2004). The social exchange relationship between supervisor and employee implies that higher levels of PSS induce OCB (Liu, Cho \& Seo, 2011). Based on these studies, we hypothesize the following:

- H1: PSS has a positive impact on OCB.

\subsection{PSS and WE}

WE is characterized by vigor, dedication and absorption on the part of employees (Bakker \& Demerouti, 2008). Supervisors who communicate with their employees effectively and help them organize their work, carry out their assigned tasks and develop their skills are more likely to generate self-confidence and motivation. This, in turn, is associated with higher levels of WE (Chughtai \& Buckley, 2008). Olivier and Rothmann (2007) show that meaningfulness, safety and availability are prerequisites for creating conditions conducive to WE. Kular et al. (2008) argue that WE depends on whether employees' immediate supervisor practices 'servant leadership'. Based on these findings, we hypothesize the following:

- H2: PSS has a positive impact on WE.

\subsection{WE and $O C B$}

The literature shows that the more involved employees are in their work, the more likely they are to display intrinsic motivation and carry out tasks over and above their formal job requirements (Saks, 2006; Kataria, Garg \& Rastogi, 2013; Ariani, 2013; Rich, Lepine \& Crawford, 2010). Based on social exchange theory, OCB is an outcome of WE because such employees act on the principal of reciprocity. Thus, there is a positive relationship between WE and OCB (Ahmed, Rasheed \& Jehanzeb, 2012). Schaufeli et al. (2002) describe WE as a positive work-related state of mind that enables employees to work harder because it involves new opportunities, information and experiences (Bakker \& Demerouti, 2008). Based on these studies, we hypothesize the following:

- H3: WE has a positive impact on OCB.

- H4: WE mediates the relationship between PSS and OCB. 


\section{Introversion}

\subsection{Introversion as a Moderator}

In this context, we differentiate between introverts and extraverts based on their relative ability to feel engaged in their work, depending on the level of supervisor support. Most people are ambiverts: they will behave as either extraverts or introverts depending on the situation (Grant, 2013). Introverts are less likely to feel as engaged as extraverts when provided the same level of supervisor support (Atamanik, 2013). This gives rise to the following hypothesis:

- H5: When introversion is high, PSS has a weak, positive impact on WE.

Introverts are more likely to be engaged in their work, given that they are less sociable. The literature suggests that introversion is strongly related to OCB (Harper, 2015). Thus, we hypothesize the following:

- H6: When introversion is high, WE has a strong, positive impact on OCB.

Introverts are more likely to be motivated by a sense of duty or fear of punishment than by the desire to expand their work-related experience. As a result, they tend to remain focused on routine tasks as opposed to additional tasks. Thus, introversion has a weak relationship with OCB (Shoaeshargh \& Dadashi, 2013; Hakim et al., 2014). Van Emmerik and Euwema (2007) show that teachers are less likely to exhibit OCB because they have limited social interaction with their colleagues. This supports the following hypothesis:

- H7: When introversion is high, PSS has a weak, positive impact on OCB.

Figure 1 shows how WE mediates the relationship between PSS and $\mathrm{OCB}$ and how introversion acts as a moderator in this relationship.

\section{Figure 1: Relationship between WE, PSS, OCB and introversion}

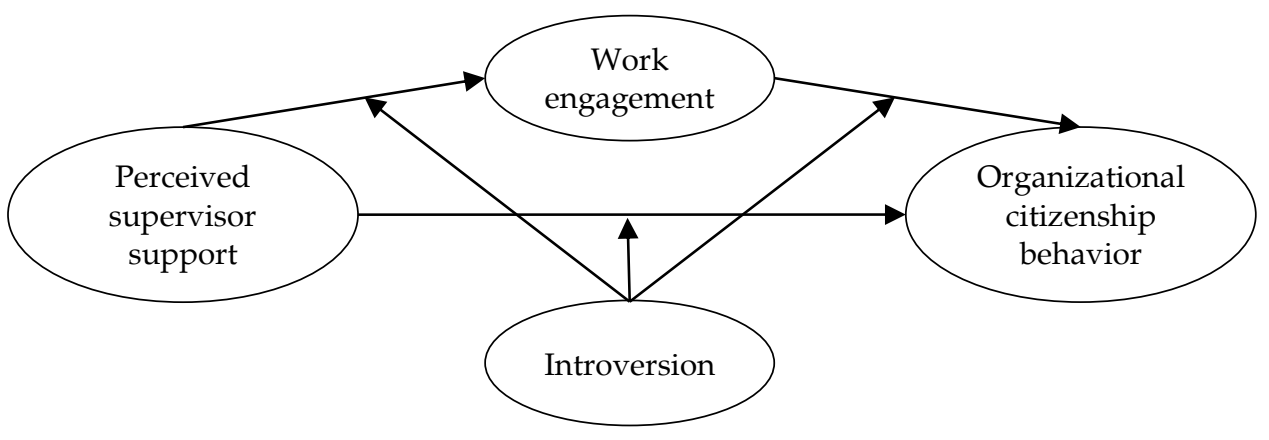




\section{Dataset and Methodology}

The data for this study was collected from seven private educational institutions in Pakistan. The questionnaire was designed based on input from a focus group of four subject specialists and translated into Urdu (see Appendix). Using a nonprobability convenience sampling method, we distributed 650 questionnaires, of which 600 were returned. Another 14 were dropped due to missing values identified using the hot deck imputation method, whereby missing values are replaced with data from a similar observed response (Andridge \& Little, 2010). This yields a total sample of 586 respondents.

Table 1 gives the sample characteristics. More than two thirds of the sample (68 percent) comprised male respondents. Almost half the sample (47 percent) was aged 18-28 years, followed by 44 percent in the $29-40$ age group. About a third of the respondents had an intermediate degree and almost half had an undergraduate degree. Most respondents had worked for their current organization for up to two years (42 percent) or up to five years (37 percent).

Table 1: Descriptive statistics

\begin{tabular}{llc}
\hline & Sample characteristics & Percentage \\
\hline Gender & Female & $32 \%$ \\
Age & Male & $68 \%$ \\
& $18-28$ years & $47 \%$ \\
& $29-40$ years & $44 \%$ \\
& $41-55$ years & $7 \%$ \\
Level of education & $>55$ years & $2 \%$ \\
& Intermediate & $32 \%$ \\
& Undergraduate & $47 \%$ \\
Job tenure & Postgraduate & $12 \%$ \\
& Professional degree & $2 \%$ \\
& $0-2$ years & $42 \%$ \\
& $3-5$ years & $37 \%$ \\
& $6-10$ years & $17 \%$ \\
\hline
\end{tabular}

Note: Percentage values are rounded off.

Source: Authors' calculations. 
The PSS variable is measured using four items adapted from Rhoades, Eisenberger and Armeli (2001). WE is measured using five items adapted from Bledow et al. (2011). OCB is measured using four items adapted from Podsakoff et al. (1990) and introversion is measured using three items adapted from Brown et al. (2002). The questionnaire was administered in both English and Urdu and each item examined closely for any translation problems. The items are measured on a sevenpoint Likert scale ranging from 1 ('strongly disagree') to 7 ('strongly agree'). The survey itself was preceded by a pilot comprising 15 questionnaires to fine-tune the design.

\section{Analysis and Results}

This section discusses the study's results.

\subsection{Descriptive Statistics and Correlation Matrix}

Table 2 gives the zero-order correlations, mean and standard deviation of all the scales. As expected, PSS, WE and OCB are strongly correlated with introversion.

Table 2: Descriptive statistics and correlation matrix

\begin{tabular}{lcccccccc}
\hline Variable & Mean & SD & $\mathbf{1}$ & $\mathbf{2}$ & $\mathbf{3}$ & $\mathbf{3}$ & $\mathbf{4}$ & $\mathbf{5}$ \\
\hline Gender & 1.1600 & 0.640 & 1.000 & & & & & \\
Age & 1.4200 & 0.850 & $0.449^{* *}$ & 1.000 & & & & \\
PSS & 5.4804 & 1.100 & 0.075 & $0.085^{*}$ & 1.000 & & & \\
WE & 5.7973 & 0.910 & -0.074 & -0.040 & $0.236^{* *}$ & 1.000 & & \\
OCB & 5.7675 & 0.100 & -0.009 & 0.069 & $0.436^{* *}$ & $0.399^{* *}$ & 1.000 & \\
Introversion & 4.9659 & 1.342 & $0.126^{* *}$ & $0.139^{* *}$ & $0.151^{* *}$ & $0.207^{* *}$ & $0.295^{* *}$ & 1.000 \\
\hline
\end{tabular}

Source: Authors' calculations.

\subsection{Confirmatory Factor Analysis}

We carry out a confirmatory factor analysis (CFA) to determine if the three support-related variables, PSS, WE and OCB, are distinct theoretical constructs. The results indicate that a four-factor model provides the best data fit while a one-factor model (combining all four constructs) yields an acceptable model fit (Table 3). This supports the argument that PSS, WE and OCB are distinct constructs. 
Table 3: Alternative CFA model

\begin{tabular}{lrrcccccc}
\hline Model & Chi-sq. & \multicolumn{1}{c}{ df } & RRMSEA & NFI & CFI & GFI & AGFI & IFI \\
\hline One-factor & 28.154 & 104 & 0.215 & 0.374 & 0.374 & 0.547 & 0.407 & 0.440 \\
Four-factor & 4.339 & 98 & 0.076 & 0.917 & 0.935 & 0.920 & 0.889 & 0.935 \\
\hline
\end{tabular}

Source: Authors' calculations.

\subsection{Validity and Reliability}

Following Kline (2011), all the items achieve high factor loadings of between 0.62 and 0.90 in the four-factor model. Next, we measure the convergent validity, discriminant validity and reliability of the four instruments. The average variance extracted (AVE) of all four is greater than the recommended value of 0.50 , indicating a satisfactory level of convergent validity (Table 4). The AVE of each construct is greater than any squared correlation, which establishes their discriminant validity. All four constructs show a high level of internal consistency and reliability, with Cronbach alpha values that are all greater than the recommended value of 0.7 (see Nunnally \& Bernstein, 1994).

Table 4: Validity and reliability scores

\begin{tabular}{lcccccc}
\hline Variable & AVE & $\mathbf{1}$ & $\mathbf{2}$ & $\mathbf{3}$ & $\mathbf{4}$ & $\boldsymbol{\alpha}$ \\
\hline WE & 0.612 & 0.782 & & & & 0.88 \\
PSS & 0.658 & 0.224 & 0.811 & & & 0.88 \\
Introversion & 0.524 & 0.206 & 0.173 & 0.724 & & 0.75 \\
OCB employees & 0.618 & 0.372 & 0.463 & 0.291 & 0.786 & 0.86 \\
\hline
\end{tabular}

Note: The diagonal values in the correlation of constructs matrix are the square root of the AVE. For adequate discriminant validity, these should be greater than the corresponding off-diagonal values.

Source: Authors' calculations.

\subsection{Common Method Variance and Goodness of Fit}

Data that is self-reported and collected using a cross-sectional questionnaire in the same period is potentially subject to common method bias (CMB) (Podsakoff et al., 2003). We apply one-factor CFA, Harman's one-factor method and common latent factors to test for the existence of $\mathrm{CMB}$. The principal component analysis of all the variables produces four distinct factors, which together account for 71 percent of the total variance (the first factor accounts for only 34 percent). The common method latent factor test for the independent mediator and dependent variables yields a 

Introversion

score less than the acceptable threshold of 25 percent (see Podsakoff et al., 2003). Thus, CMB does not pose a serious problem in this case.

The results in Table 5 indicate that the one-factor model provides the best fit (adjusted goodness-of-fit index $=0.900$ ).

Table 5: Goodness-of-fit indices

\begin{tabular}{lcccccccc}
\hline Model & Chi-sq. & df & RRMSEA & NFI & CFI & GFI & AGFI & IFI \\
\hline One-factor & 4.681 & 61 & 0.079 & 0.932 & 0.945 & 0.933 & 0.900 & 0.946 \\
\hline
\end{tabular}

Source: Authors' calculations.

\subsection{Direct and Indirect Effects of PSS}

The results in Table 6 support the first hypothesis of a positive relationship between PSS and OCB $(0.38, p<0.001)$ as well as the second hypothesis of a positive relationship between PSS and WE $(0.22, p<0.001)$. The relationship between WE and OCB is also significant $(0.33, p<0.001)$.

Before examining the indirect effect of supervisor support on OCB when mediated by WE, we measure its direct effect. The results show that PSS has a positive impact on OCB (direct effect: $0.38, p<0.001$ ). The results also support the third hypothesis concerning the indirect effect of PSS and OCB $(0.073, p<0.001)$, that is, WE mediates the relationship between PSS and OCB.

Table 6: Direct and indirect effects

\begin{tabular}{lccccc}
\hline & \multicolumn{5}{c}{ Dependent variables } \\
\cline { 2 - 6 } Independent & WE & \multicolumn{4}{c}{ OCB } \\
\cline { 2 - 6 } variables & $\begin{array}{c}\text { Direct } \\
\text { effect }\end{array}$ & $\begin{array}{c}\text { Direct } \\
\text { effect }\end{array}$ & $\begin{array}{c}\text { Indirect } \\
\text { effect }\end{array}$ & $\begin{array}{c}\text { Total } \\
\text { effect }\end{array}$ & $\begin{array}{c}\% \\
\text { Mediation }\end{array}$ \\
\hline PSS & $0.22^{* * *}$ & $0.38^{* * *}$ & $0.07^{* * *}$ & $0.45^{* * *}$ & $16 \%$ \\
WE & & $0.33^{* * *}$ & & & \\
\hline
\end{tabular}

Source: Authors' calculations.

\subsection{Moderating Effects}

In Table 7, model 1 shows that introversion does not moderate the direct relationship between PSS and WE because the interaction value is $0.004(p>0.005)$. Thus, we reject the fifth hypothesis. Model 2 recognizes that introversion acts as a positive moderator in the direct relationship 
between WE and OCB (interaction $=0.08, p<0.05$ ). When introversion is low, the positive effect of WE on OCB is $0.34(p<0.001)$. When introversion is high, the direct effect is high $(0.51, p<0.001)$.

Table 7: Introversion as a moderator in the relationship between independent and dependent variables

\begin{tabular}{llll}
\hline Model & \multicolumn{1}{c}{ Independent variables } & WE & OCB \\
\hline Model 1 & Constant & $4.850^{* * *}$ & \\
& PSS & $0.170^{* * *}$ & \\
& Introversion & 0.140 & \\
\multirow{2}{*}{ Model 2 } & PSS x introversion & 0.004 & \\
& Constant & & $2.22^{* * *}$ \\
& WE & & $0.34^{* * *}$ \\
& Introversion & 0.28 \\
Model 3 & WE x introversion & & $0.08^{*}$ \\
& Constant & $2.22^{* * *}$ \\
& PSS & & $0.28^{* * *}$ \\
& Introversion & & 0.28 \\
& PSS x introversion & & $-0.10^{* * *}$ \\
\hline
\end{tabular}

Source: Authors' calculations.

In model 3, introversion acts as a negative moderator in the relationship between PSS and OCB (interaction $=-0.10, p<0.001$ ). A low level of moderation yields an interaction term of $0.39(p<0.001)$ and a high level yields $0.18(p<0.001)$. Moreover, introversion moderates the relationship between PSS and OCB through WE (low $=0.045, p<0.05$; high $=0.075, p<0.05)($ Table 8$)$.

Table 8: Moderated mediation analysis

\begin{tabular}{lllcc}
\hline Independent & \multicolumn{2}{c}{ Moderator } & \multicolumn{2}{c}{ OCB } \\
\cline { 4 - 5 } variable & & & Direct effect & Indirect effect via WE \\
\hline PSS & Introversion & Low & $0.39^{* * *}$ & $0.045^{*}$ \\
& Introversion & High & $0.18^{* * *}$ & $0.075^{*}$ \\
WE & Introversion & Low & $0.34^{* * *}$ & \\
& Introversion & High & $0.51^{* * *}$ & \\
\hline
\end{tabular}

Source: Authors' calculations.

\section{Discussion}

This study examines the impact of PSS on OCB, where WE plays a mediating role and introversion acts as a moderator. Our findings support 
the literature, which suggests that two cognitive mechanisms and an affective mechanism govern the relationship between PSS and OCB (Chen \& Chiu, 2008). While supervisor support increases employee OCB (Jung \& Avolio, 2000), Podsakoff et al. (2000) indicate that one should look beyond the causal relationship between the two. Accordingly, we identify WE as a mediator in this relationship and introversion as a moderator.

Our results show that PSS has a positive and significant impact on OCB. This is in line with studies such as Chughtai and Buckley (2008), who find that better supervisor support and communication between employee and supervisor generate self-confidence, motivating employees to work harder. Employees with a higher level of WE are more likely to be characterized by contextual performance (Kataria et al., 2013), whereby they reciprocate in the form of OCB, taking on additional tasks to meet the organization's goals (Ariani, 2013).

We also find that introversion acts as a negative moderator in the relationship between supervisor support and employee OCB: low levels of introversion are associated with higher OCB in the presence of supervisor support. The results indicate that introversion moderates the relationship between PSS and OCB indirectly through WE. In this case, higher levels of introversion are associated with higher OCB because introverts are more likely to focus on their work. Introversion is thus strongly related to OCB (Harper, 2015).

\section{Conclusion}

Having established that PSS is an important antecedent of OCB, we find that the relationship is mediated by WE. Supervisors who value their employees induce greater job satisfaction and WE, leading in turn to higher OCB. PSS strongly influences OCB in the case of high levels of introversion when the relationship is mediated by WE. This suggests that supervisors should identify and support introverted employees to encourage WE and drive OCB. Employees who are less introverted, however, are associated directly with OCB, where the effect is stronger and positive.

The study's main limitation is that it examines only one personality trait, i.e., introversion. Future research could look at other traits to see how they affect the relationship between PSS and OCB. 


\section{References}

Ahmed, N., Rasheed, A., \& Jehanzeb, K. (2012). An exploration of predictors of organizational citizenship behavior and its significant link to employee engagement. International Journal of Business, Humanities and Technology, 2(4), 99-106.

Andridge, R. R., \& Little, R. (2010). A review of hot deck imputation for survey non-response. International Statistical Review, 78(1), 40-64.

Ariani, D. W. (2013). The relationship between employee engagement, organizational citizenship behavior and counterproductive work behavior. International Journal of Business Administration, 4(2), 46-56.

Arora, V., \& Kamalanabhan, T. J. (2013, March). Linking supervisor and coworker support to employee innovative behavior at work: Role of psychological conditions. Paper presented at the AABRI International Conference, New Orleans, LA.

Atamanik, C. (2013). The introverted leader: Examining the role of personality and environment (Paper No. 2). Miami. FIU Center for Leadership.

Azman, I., Sieng, L. L. C., Ajis, M. N., ... Boerhannoeddin, A. (2009). Relationship between supervisor's role and job performance in the workplace training program. Scientific Annals of Economics and Business, 56, 237-251.

Bakker, A. B., \& Demerouti, E. (2008). Towards a model of work engagement. Career Development International, 13(3), 209-223.

Baloyi, S., van Waveren, C. C., \& Chan, K.-Y. (2014). The role of supervisor support in predicting employee job satisfaction from their perception of the performance management system: A test of competing models in engineering environments. South African Journal of Industrial Engineering, 25(1), 85-95.

Barnard, C. (1938). The functions of the executive. Cambridge, MA: Harvard University Press.

Bhatnagar, J. (2014). Mediator analysis in the management of innovation in Indian knowledge workers: The role of perceived supervisor support, psychological contract, reward and recognition and 

Introversion

turnover intention. International Journal of Human Resource Management, 25(10), 1395-1416.

Bledow, R., Frese, M., Schmitt, A., \& Kuhnel, J. (2011). The affective shift model of work engagement. Journal of Applied Psychology, 96(6), 1246-1257.

Bolino, M. C., Turnley, W. H., \& Bloodgood, J. M. (2002). Citizenship behavior and the creation of social capital in organizations. Academy of Management Review, 27(4), 505-522.

Brough, P., \& Pears, J. (2004). Evaluating the influence of the type of social support on job satisfaction and work-related psychological wellbeing. International Journal of Organizational Behavior, 8(2), 472-485.

Brown, T. J., Mowen, J. C., Donavan, D. T., \& Licata, J. W. (2002). The customer orientation of service workers: Personality trait effects on self- and supervisor performance ratings. Journal of Marketing Research, 39(1), 110-119.

Byrne, Z. S., Pitts, V. E., Wilson, C. M., \& Steiner, Z. J. (2012). Trusting the fair supervisor: The role of supervisory support in performance appraisals. Human Resource Management Journal, 22(2), 129-147.

Calderón, J. P., Battistelli, A., \& Odoardi, C. (2013). Work engagement as mediator between perceived participation, supervisor support and altruistic behaviors: Empirical results from the Italian social enterprise sector. Universitas Psychologica, 12(3), 899-909.

Chen, C.-C., \& Chiu, S.-F. (2008). An integrative model linking supervisor support and organizational citizenship behavior. Journal of Business and Psychology, 23(1), 1-10.

Chughtai, A. A., \& Buckley, F. (2008). Work engagement and its relationship with state and trait trust: A conceptual analysis. Journal of Behavioral and Applied Management, 10(1), 47-71.

DeConinck, J. B., \& Johnson, J. T. (2009). The effects of perceived supervisor support, perceived organizational support and organizational justice on turnover among salespeople. Journal of Personal Selling and Sales Management, 29(4), 333-350. 
Deniz, N., Noyan, A., \& Ertosun, Ö. G. (2015). Linking person-job fit to job stress: The mediating effect of perceived person-organization fit. Procedia - Social and Behavioral Sciences, 207, 369-376.

Eisenberger, R., Stinglhamber, F., Vandenberghe, C., ... Rhoades, L. (2002). Perceived supervisor support: Contributions to perceived organizational support and employee retention. Journal of Applied Psychology, 87(3), 565-573.

Emami, M., Alizadeh, Z., Nazari, K., \& Darvishi, S. (2012). Antecedents and consequences of organizational citizenship behavior (OCB). Interdisciplinary Journal of Contemporary Research in Business, 3(9), 494-505.

Foote, D. A., \& Tang, T. L.-P. (2008). Job satisfaction and organizational citizenship behavior (OCB): Does team commitment make a difference in self-directed teams? Management Decision, 46(6), 933-947.

Galletta, M., Portoghese, I., Penna, M. P., ... Saiani, L. (2011). Turnover intention among Italian nurses: The moderating roles of supervisor support and organizational support. Nursing and Health Sciences, 13(2), 184-191.

Grant, A. M. (2013). Rethinking the extraverted sales ideal: The ambivert advantage. Psychological Science, 24(6), 1024-1030.

Griffin, M. A., Patterson, M. G., \& West, M. A. (2001). Job satisfaction and teamwork: The role of supervisor support. Journal of Organizational Behavior, 22(5), 537-550.

Hakim, W., Nimran, U., Haerani, S., \& Alam, S. (2014). The antecedents of organizational citizenship behavior (OCB) and their effect on performance: Study on public university in Makassar, South Sulawesi, Indonesia. IOSR Journal of Business and Management, 16(2), 5-13.

Harper, P. J. (2015). Exploring forms of organizational citizenship behaviors (OCB): Antecedents and outcomes. Journal of Management and Marketing Research, 18, 1-16. 

Introversion

Ismail, A. B., Sieng, L. L. C., Abdullah, M. M. B., \& Francis, S. K. (2010). Linking supervisor's role in training programs to motivation to learn as an antecedent of job performance. Intangible Capital, 6(1), $1-25$.

Jung, D. I., \& Avolio, B. J. (2000). Opening the black box: An experimental investigation of the mediating effects of trust and value congruence on transformational and transactional leadership. Journal of Organizational Behavior, 21(8), 949-964.

Kataria, A., Garg, P., \& Rastogi, R. (2013). Employee engagement and organizational effectiveness: The role of organizational citizenship behavior. International Journal of Business Insights and Transformation, 6(1), 102-113.

Kidd, J. M., \& Smewing, C. (2001). The role of the supervisor in career and organizational commitment. European Journal of Work and Organizational Psychology, 10(1), 25-40.

Kline, R. B. (2011). Convergence of structural equation modeling and multilevel modeling. In M. Williams \& W. P. Vogt (Eds.), Handbook of methodological innovation in social research methods (pp. 562-589). London: Sage.

Kular, S., Gatenby, M., Rees, C., ... Truss, K. (2008). Employee engagement: A literature review (Working Paper No. 19). London: Kingston Business School.

Kuvaas, B., \& Dysvik, A. (2010). Exploring alternative relationships between perceived investment in employee development, perceived supervisor support and employee outcomes. Human Resource Management Journal, 20(2), 138-156.

Lapierre, L. M., \& Hackett, R. D. (2007). Trait conscientiousness, leadermember exchange, job satisfaction and organizational citizenship behavior: A test of an integrative model. Journal of Occupational and Organizational Psychology, 80(3), 539-554.

Liaw, Y.-J., Chi, N.-W., \& Chuang, A. (2010). Examining the mechanisms linking transformational leadership, employee customer orientation and service performance: The mediating roles of 
perceived supervisor and coworker support. Journal of Business and Psychology, 25(3), 477-492.

Liu, J., Cho, S., \& Seo, W. (2011, January). OCB: Investigating the impact of psychological contract and perceived supervisor support in the hospitality industry in South Korea. Paper presented at the $16^{\text {th }}$ Graduate Students Research Conference, Houston, TX.

Lu, C.-S., \& Lin, C.-C. (2014). The effects of ethical leadership and ethical climate on employee ethical behavior in the international port context. Journal of Business Ethics, 124(2), 209-223.

Maertz, C. P., Griffeth, R. W., Campbell, N. S., \& Allen, D. G. (2007). The effects of perceived organizational support and perceived supervisor support on employee turnover. Journal of Organizational Behavior, 28(8), 1059-1075.

Neves, P., \& Caetano, A. (2009). Commitment to change: Contributions to trust in the supervisor and work outcomes. Group and Organization Management, 34(6), 623-644.

Nunnally, J. C., \& Bernstein, I. H. (1994). Psychometric theory. New York: McGraw-Hill.

Olivier, A. L., \& Rothmann, S. (2007). Antecedents of work engagement in a multinational oil company. SA Journal of Industrial Psychology, 33(3), 49-56.

Organ, D. W. (1997). Organizational citizenship behavior: It's construct clean-up time. Human Performance, 10(2), 85-97.

Organ, D. W., Podsakoff, P. M., \& MacKenzie, S. B. (2006). Organizational citizenship behavior: Its nature, antecedents and consequences. Thousand Oaks, CA: Sage.

Paillé, P., \& Grima, F. (2011). Citizenship and withdrawal in the workplace: Relationship between organizational citizenship behavior, intention to leave current job and intention to leave the organization. Journal of Social Psychology, 151(4), 478-493.

Podsakoff, P. M., MacKenzie, S. B., Lee, J.-Y., \& Podsakoff, N. P. (2003). Common method biases in behavioral research: A critical review 

Introversion

of the literature and recommended remedies. Journal of Applied Psychology, 88(5), 879-903.

Podsakoff, P. M., MacKenzie, S. B., Moorman, R. H., \& Fetter, R. (1990). Transformational leader behaviors and their effects on followers' trust in leader, satisfaction and organizational citizenship behaviors. Leadership Quarterly, 1(2), 107-142.

Podsakoff, P. M., MacKenzie, S. B., Paine, J. B., \& Bachrach, D. G. (2000). Organizational citizenship behaviors: A critical review of the theoretical and empirical literature and suggestions for future research. Journal of Management, 26(3), 513-563.

Rashid, W. E. W., Nordin, M. S., Omar, A., \& Ismail, I. (2012, May). Supervisor support, work/family conflict and employee satisfaction among nurses in healthcare service. Paper presented at the International Conference on Innovation Management and Technology Research, Malacca, Malaysia.

Rhoades, L., \& Eisenberger, R. (2002). Perceived organizational support: A review of the literature. Journal of Applied Psychology, 87(4), 698-714.

Rhoades, L., Eisenberger, R., \& Armeli, S. (2001). Affective commitment to the organization: The contribution of perceived organizational support. Journal of Applied Psychology, 86(5), 825-836.

Rich, B. L., Lepine, J. A., \& Crawford, E. R. (2010). Job engagement: Antecedents and effects on job performance. Academy of Management Journal, 53(3), 617-635.

Saks, A. M. (2006). Antecedents and consequences of employee engagement. Journal of Managerial Psychology, 21(7), 600-619.

Schaufeli, W. B., Salanova, M., González-romá, V., \& Bakker, A. B. (2002). The measurement of engagement and burnout: A two-sample confirmatory factor analytic approach. Journal of Happiness Studies, 3(1), 71-92.

Shoaeshargh, F., \& Dadashi, M. A. (2013). Analyzing the relationship between personality type (extrovert-introvert) and organizational citizenship behavior in Shoa e Shargh concrete company. Technical Journal of Engineering and Applied Sciences, 3(18), 2159-2162. 
Soulen, S. K. (2003). Organizational commitment, perceived supervisor support and performance: A field study. Unpublished Master's thesis, University of Tennessee, Knoxville, TN.

Steinhardt, M. A., Dolbier, C. L., Gottlieb, N. H., \& McCalister, K. T. (2003). The relationship between hardiness, supervisor support, group cohesion and job stress as predictors of job satisfaction. American Journal of Health Promotion, 17(6), 382-389.

van Emmerik, I. H., \& Euwema, M. C. (2007). Who is offering a helping hand? Associations between personality and OCBs, and the moderating role of team leader effectiveness. Journal of Managerial Psychology, 22(6), 530-548.

Wang, Z. (2014). Perceived supervisor support and organizational citizenship behavior: The role of organizational commitment. International Journal of Business and Social Science, 5(1), 210-214.

Zhang, D. (2011). Organizational citizenship behavior. Unpublished manuscript, University of Auckland. Retrieved from https://cdn.auckland.ac.nz/assets/psych/about/ourpeople/documents/Deww Zhang - Organisational Citizenship Behaviour - White Paper.pdf 


\section{Questionnaire}

\section{Part 1}

Please mark one option in response to the following questions:

1. Nationality:

2. Gender:

- Male

- Female

3. Age:

- 18 to 28 years

- 29 to 40 years

- 41 to 55 years

- Over 55 years

4. Educational qualification:

5. Name of the company where you work:

6. How long have you worked at this company (years)?

7. What is your primary responsibility?

- General manager

- Faculty member

- Administration or finance

- Human resources

- Marketing or sales

- Technical, lab staff, etc.

8. What is your role?

- Senior management

- Middle management

- Supervisory

- Nonmanagement technical or professional 


\section{Part 2}

Keeping in mind the company you work for, please rank the statements below. Mark the single most appropriate option on the righthand side (1-7). Mark 1 if you disagree strongly with the statement and 7 if you agree strongly with the statement. If you agree or disagree to some extent, mark 3, 4 or 5 to indicate this. Please note that there is no wrong or right answer.

\begin{tabular}{|c|c|c|c|c|c|c|c|}
\hline 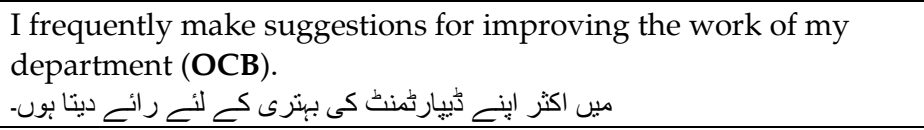 & 1 & 2 & 3 & 4 & 5 & 6 & 7 \\
\hline 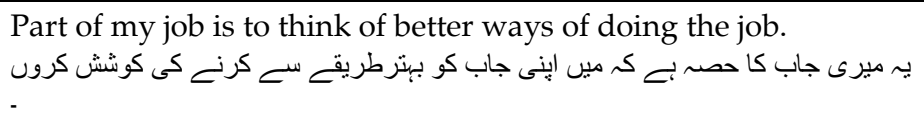 & 1 & 2 & 3 & 4 & 5 & 6 & 7 \\
\hline 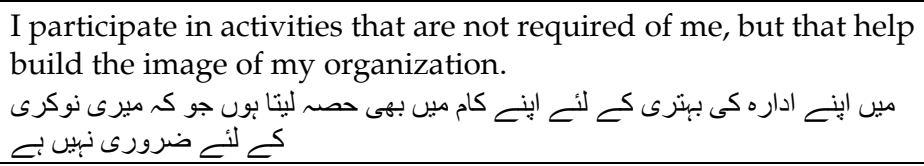 & 1 & 2 & 3 & 4 & 5 & 6 & 7 \\
\hline 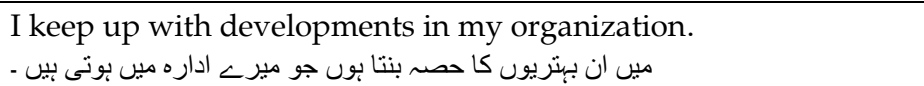 & 1 & 2 & 3 & 4 & 5 & 6 & 7 \\
\hline 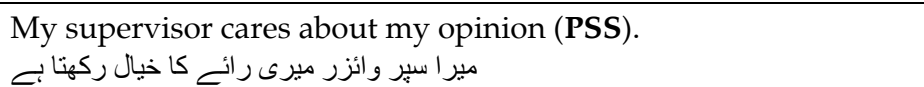 & 1 & 2 & 3 & 4 & 5 & 6 & 7 \\
\hline 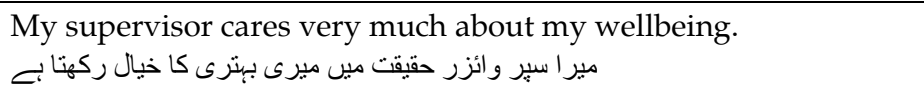 & 1 & 2 & 3 & 4 & 5 & 6 & 7 \\
\hline $\begin{array}{l}\text { My supervisor strongly considers my goals and values. } \\
\text { مبرا سبر وائزر مبرح مقاصد كا خيال ركها بـ. }\end{array}$ & 1 & 2 & 3 & 4 & 5 & 6 & 7 \\
\hline 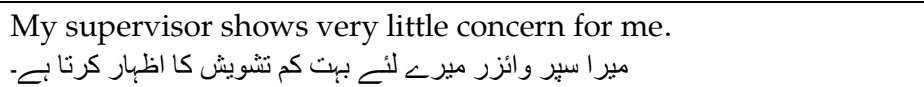 & 1 & 2 & 3 & 4 & 5 & 6 & 7 \\
\hline $\begin{array}{l}\text { I feel strong and vigorous about my work (WE). } \\
\text { مين اينه كام كوران برجوش محسوس كرنا بوب }\end{array}$ & 1 & 2 & 3 & 4 & 5 & 6 & 7 \\
\hline 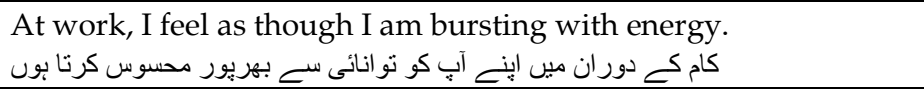 & 1 & 2 & 3 & 4 & 5 & 6 & 7 \\
\hline 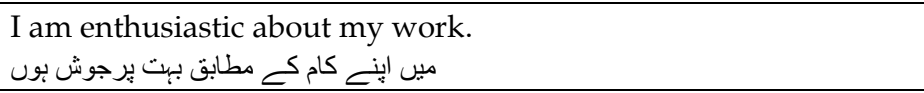 & 1 & 2 & 3 & 4 & 5 & 6 & 7 \\
\hline $\begin{array}{l}\text { My work inspires me. } \\
\text { مير ا كام مجه مناثر كرنا بـح- }\end{array}$ & 1 & 2 & 3 & 4 & 5 & 6 & 7 \\
\hline $\begin{array}{l}\text { I am happily engrossed in my work. } \\
\text { مير كام مجه متاثر كرنا بـ }\end{array}$ & 1 & 2 & 3 & 4 & 5 & 6 & 7 \\
\hline 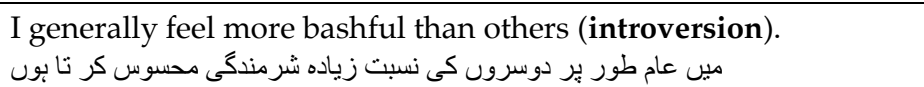 & 1 & 2 & 3 & 4 & 5 & 6 & 7 \\
\hline 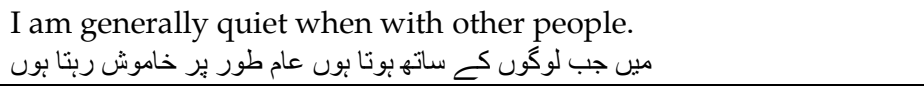 & 1 & 2 & 3 & 4 & 5 & 6 & 7 \\
\hline $\begin{array}{l}\text { I am generally shy. } \\
\text { مين عام طور بر شرمو حياوالابون }\end{array}$ & 1 & 2 & 3 & 4 & 5 & 6 & 7 \\
\hline
\end{tabular}

